\title{
Validation of an Indicator Model (INCODIES) for Assessing Student Digital Competence in Basic Education
}

\author{
Ana García-Valcárcel Muñoz-Repiso ${ }^{1}$ (D), Sonia Casillas Martín ${ }^{1}$ (i) and Verónica Basilotta \\ Gómez-Pablos ${ }^{2}$ (D)
}

${ }^{1}$ Departamento Didáctica, Organización y Métodos de investigación, Universidad de Salamanca, Spain

${ }^{2}$ Departamento de Educación, Universidad a distancia de Madrid, Spain

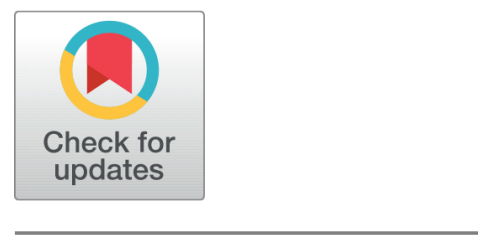

Received 2019-07-18

Revised 2019-09-06

Accepted 2019-10-07

Published 15-01-20

Corresponding Author

Ana García-Valcárcel

Muñoz-Repiso,

anagv@usal.es

Facultad de Educación. Paseo de Canalejas, 169, 37008,

Salamanca, Spain

DOI https://doi.org/10.7821/

naer.2020.1.459

Pages: 110-125

Funding: Ministry of Economy and Competitiveness \& European Regional Development Fund (FEDER), Spain (Award: EDU2015-67975-C3-3-P)

Distributed under

Creative Commons CC BY 4.0

Copyright: (c) The Author(s)

\section{ABSTRACT}

Digital competence is a basic skill for citizens and should be systematically assessed, taking into account characteristics such as knowledge, skills and attitudes. However, measuring and identifying the digital competence of students is still a major challenge. To this end, the indicator model (INCODIES) has been developed and validated following the structure of the DIGCOMP model, which can be used to create assessment tests that measure student digital competence when they have completed their compulsory education. This article presents the results of a process of content validation carried out by 77 experts, in both the school and the university context. The analysis of the experts' assessments and the level of agreement among those rating them were carried out following an original method which consists of determining a quantitative index for the validity of content called the Content Validity Ratio (CVR). The results obtained allowed us to confirm that the competences included in the reference framework DIGCOMP are correctly represented in the items formulated for the INCODIES model, which obtained high content validity. The model can serve as a structure and basis for the designing of specific evaluation tests on this topic.

\section{Keywords BASIC LIFE SKILLS, STUDENT EVALUATION, EDUCATIONAL INDICATORS, BASIC EDUCATION, DIGITAL TECHNOLOGY}

\section{INTRODUCTION}

A society based on information and knowledge requires training in the appropriate use of digital technologies. For this reason, the development of digital competence is included in the proposed national curriculum as one of the basic competences within compulsory education (Matamala, 2014). In this regard three potential contexts can be distinguished for developing these skills: the formal teaching-learning process developed in schools; the socio-familial context; and that of peer relations (Dardanou \& Kofoed, 2019).

\section{OPEN ACCESS}


Over the past few decades the term digital competence has emerged, linked from the onset to new media literacy (Lee, Chen, Li, \& Lin, 2015). This concept has progressed from centring on the critical interpretation of different audiovisual and artistic manifestations to focusing on aspects related to access to technology (Esteve, Gisbert, \& Lázaro, 2016).

Nowadays, it is considered that digital competence is one of the key competences and is necessary for lifelong learning as it "involves the confident and critical use of electronic media for work, leisure and communication. It is related to logical and critical thinking, to skills for handling information at a high level" (European Comission, 2007, p.9). According to Gisbert and Esteve (2011) digital competence is considered as the sum of a series of skills, knowledge and attitudes concerning technological, informational, multimedia and communicative aspects that give rise to complex multiple literacy.

In recent years, there has been a growing interest in the evaluation and certification of digital competences by various institutions (e.g. educational administrations, the European Community, etc.) (Stopar \& Bartol, 2019) . This has resulted in the proposal of different models that have tried to define and standardize digital competence, drawn up by different institutions (García-Valcárcel, 2016; García-Valcárcel \& Tejedor, 2017). A model that stands out at the European level is the DIGCOMP project (Ferrari, 2013), which has developed a conceptual framework of digital competence in which its dimensions or indicators are identified in terms of knowledge, skills and attitudes. These indicators were identified by European experts. The resulting report distinguished five main areas: Information, Communication, Content Creation, Security and Problem Solving. These areas make up digital competence and include 21 sub-competences, all of which refer to the key learning areas that allow citizens to adapt to life in the 21st century (Enochsson, 2019; Hernández \& Iglesias, 2017).

It is also worth highlighting the digital competence framework proposed by the International Society for Technology in Education (ISTE, 2016), which was developed through the use of different standards. Additionally, the DigEuLit model, a conceptual framework of digital competence led by the University of Glasgow and funded by the European Commission, is of particular interest, as it aims to define, structure and select a set of tools related to digital competence for educators and students (Amaro, Oliveira, \& Veloso, 2017).

While these models provide relevant information on the components and dimensions of digital competence, most provide a set of recommendations but do not provide sufficient information on how to apply them within the school curriculum. The indicators for evaluation have not yet been clearly defined, issue to be addressed by our research.

\subsection{Assessment of digital competence: previous studies and current outlook}

In the context of digital competence, a clear differentiation can be made among the different types of research based on the tools they use to evaluate the competences: on one hand, studies that focus on individual self-perception; and on the other, those that aim to truly examine an individual's level of competence through problem-solving tests. In the first case, the image that individuals have of themselves concerning different aspects related to digital 
competence are analysed, while in the second case, the individuals' level of competence is measured.

It is worth noting the studies on self-perception that focus on the informational dimension of digital competence. From this perspective, the work of Colás, Conde, and Reyes (2017) analyses the perception of primary and secondary school students on their digital competence, using a Likert scale adapted from the theoretical model proposed by AlaMutka (2011). In their study, Rodríguez, Olmos, and Martínez (2012) analyse the perception of university students through an assessment scale called IL-HUMASS (Pinto, 2009; Pinto \& Guerrero, 2017). Likewise, some works have approached the assessment of media competence in preschool education by means of a questionnaire that allows three levels of competence to be established: excellent, acceptable and minimum (García, Duarte, \& Guerra, 2014). The on-line digital literacy test (ADO) has also been proposed as an indicator of media competence (Dornaleteche, Buitrago, \& Moreno, 2015). It was applied to citizens whose results and general conclusions indicated that the level of on-line digital literacy of the average citizen was unfavourable.

In the same way, González, Espuny, Cid, and Gisbert (2012), for compulsory secondary education, and Gisbert, Espuny, and González (2011), for bachelor degrees, work with a selfperception tool called INCOTIC that evaluates six dimensions: digital resources, degree of the use of ICT in general, knowledge and use of ICT resources, culture and respect in the use of digital information, efficient access to information, levels of use and efficiency in the communication of information (Ait \& González, 2017).

In Spain, the National Institute of Educational Technologies and Teacher Training (INTEF) has opened and adapted the competences proposed by the European project DIGCOMP to the field of Education, as well as an online service for the recognition of digital teaching competence. This includes a portfolio of digital teaching competence, a service for acquiring digital competence, and the development, recognition and improvement of teachers' digital competence (MEC-INTEF, 2017).

In addition, international studies (Aesaert \& Braak, 2014; Aesaert, Voogt, Kuiper, \& Braak, 2017; Siddiq, Hatlevik, Olsen, Throndsen, \& Scherer, 2016) have focused on evaluating the degree to which different factors related to primary school students, such as the characteristics of their classroom, school and family, affect the students' digital self-efficacy and the self-perception of their digital competence.

Regarding studies that evaluate the level of digital competence (instead of selfperception), the classification offered by Oakleaf (2008) establishes three main trends: single response test, performance tests and rubrics. Likewise, the study carried out by Van Deursen and Van Dijk (2011) investigates the level of skill of the Dutch population to use the Internet (one of the main groups comprised primary and secondary students) and the factors that determine its use. These authors took into consideration four basic skills: operational, formal, information search and strategic. The findings obtained reveal the importance of the student's educational and cultural environment in the development of this competence (Van Deursen, Helsper, \& Eynon, 2016; Van Deursen \& Van Diepen, 2013). 
One of the most interesting models at the international level was developed by the Educational Testing Service (ETS). The instrument designed (iSkills) is used to evaluate skills related to critical thinking within a technological context (Katz, 2007). Other tools that assess digital competence are the Information Literacy Test (ILT) by Cameron, Wise, and Lottridge (2007), which is oriented towards universities and assesses the digital competence of individuals through single response questionnaires (Scherer, Rohatgi, \& Hatlevik, 2017). In the context of secondary education, the Instant DCA questionnaire (Calvani, Fini, Ranieri, \& Picci, 2012) is a suitable alternative to the European Computer Driving License (ECDL), which is more focused on mastering the technical skills associated with digital competence, as opposed to dimensions that are pedagogically oriented.

Once the scientific production and the initiatives developed in this field have been analysed, it can be concluded that a complete and updated indicator model is required based on a concept of digital competence with great international acceptance that constitutes a benchmark for the evaluation of this competence in the national and international context. In spite of the numerous aforementioned proposals, and the projects implemented by DIGCOMP in different contexts, the initiatives focused on the complete assessment of digital competence are rather scarce or only address some of its dimensions. In addition, there are few works that study digital competence among students of compulsory education.

\subsection{Objective of the work}

The purpose of this work is to define and validate an indicator model for evaluating the digital competences of students who had completed their compulsory schooling (INCODIES model), using DIGCOMP model as a reference. The work carried out in the context of the project "Evaluation of digital competences of students in compulsory education and the study of the influence of socio-familial variables", financed by the Spanish Ministry of Economy and Competitiveness and European Regional Development Fund (ERDF) (EDU201567975-C3-3-P).

\section{METHODOLOGY}

The method implemented is based on expert judgement, which is a procedure for estimating the content validity of a test (Escobar-Pérez \& Cuervo-Martínez, 2008)and which systematically gathers information. The steps taken are set out below.

\subsection{First step. Designing the indicator model for assessing digital competences.}

The indicators adapted to the group of students being surveyed (15-16 years old) were formulated based on the competences and levels of the DIGCOMP model (Ferrari, 2013; Vuorikari, Punie, Carretero, \& Brande, 2016). Using the same structure as the DIGCOMP model three areas of competence (knowledge, skills and attitudes) and the three levels of development (basic, intermediate and advanced) were considered. This work was carried out by groups of experts (university professors specializing in Educational Technology and 
Curriculum Design), following a method that included debate and "step by step" consensus. As a result, all proposed indicators for each of the competences were analysed and discussed in different work groups to decide on the final formulation and incorporation of each indicator. In the group discussions the items were either established, new wording was proposed, or the item was eliminated owing to its complexity or ambiguity. This process was laborious and required a great level of attention to detail in order to accurately adapt the indicators to the reference population.

The initial model consisted of 356 indicators or items (both terms are considered interchangeable) distributed among the 5 areas of digital competence (48 in the area of Information; 69 in Communication; 102 in Content Creation; 72 in Security and 65 in Problem Solving), which cover the 21 competences of the DIGCOMP model and the three levels of development.

The items (indicators) formulated attempted to represent the content (digital competence), were oriented towards the target population and fulfilled the intended purpose. The ultimate aim for generating this model of indicators was that it could be used as a reference for the subsequent creation of a test for assessing the digital competence of students who had completed their compulsory education.

The content of the model is shown in table 1 , as well as the number of indicators formulated for each competence. These refer to the three areas of competence. The precise content of the indicators can be consulted in the document "Modelo de indicadores para evaluar la competencia digital de los estudiantes tomando como referencia el modelo DIGCOMP (INCODIES)", published in the repository of the University of Salamanca ${ }^{1}$.

\subsection{Second step. Selecting the sample of raters}

To carry out the validation process of the model of indicators developed by the research team, it was necessary to select experts to act as judges to assess in detail each of the indicators, the clarity of their wording and their significance in relation to the competence defined. This was done in order to eliminate poorly formulated or unrelated indicators and to modify or adjust items, if necessary.

The judges or 'raters' were selected according to the following criteria: being an expert in the design of evaluation indicators, an expert in the content of the model (digital competence) and knowing the students being considered (in-service primary and secondary school teachers).

The sample was selected from among experts who had met the criteria established within a call made through Teacher Training Centres (CFIE) in several provinces of Castile and Leon, Cantabria, Madrid and Galicia. Therefore, the sample was comprised of experts from different autonomous communities associated with the context of the researchers' work. Contact with the persons involved was established via e-mail throughout the academic year 2017-18.

Specifically, 20 different experts were contacted for each of the areas, taking into account that each expert would only evaluate items in only one area. However, it was assumed that

\footnotetext{
${ }^{1}$ https://gredos.usal.es/handle/10366/139409
} 
Table 1 Structure of the INCODIES Indicator Model

\begin{tabular}{|c|c|c|c|}
\hline Area & Competence & $\begin{array}{l}\text { No. of indicators per compe- } \\
\text { tence }\end{array}$ & $\begin{array}{l}\text { No. of indicators per } \\
\text { Area }\end{array}$ \\
\hline \multirow[t]{3}{*}{ Information } & 1.1. Navigation, search and filtering of information & 18 & 45 \\
\hline & 1.2. Evaluation of the information & 11 & \\
\hline & 1.2. Storage and retrieval of information & 16 & \\
\hline \multirow[t]{6}{*}{ Communication } & 2.1. Interaction using new technologies & 13 & 66 \\
\hline & 2.2. Sharing information and content & 12 & \\
\hline & 2.3. Online Citizen Participation & 8 & \\
\hline & 2.4. Collaboration using digital channels & 10 & \\
\hline & 2.5. Netiquette & 12 & \\
\hline & 2.6. Digital identity management & 11 & \\
\hline \multirow[t]{4}{*}{ Content creation } & 3.1. Content development & 34 & 86 \\
\hline & 3.2. Integration and reprocessing & 20 & \\
\hline & 3.3. Copyright and Licensing & 19 & \\
\hline & 3.4. Programming & 13 & \\
\hline \multirow[t]{4}{*}{ Security } & 4.1. Device Protection & 18 & 72 \\
\hline & 4.2. Protection of personal data & 16 & \\
\hline & 4.3. Health protection & 22 & \\
\hline & 4.4. Protection of the environment & 16 & \\
\hline \multirow[t]{4}{*}{ Troubleshooting } & 5.1. Solving technical problems & 14 & 56 \\
\hline & 5.2. Identification of technological needs and responses & 16 & \\
\hline & 5.3. Innovate and use technology creatively & 13 & \\
\hline & 5.4. Identification of gaps in digital competition & 13 & \\
\hline TOTAL & & 325 & 325 \\
\hline
\end{tabular}

10 experts would provide a reliable estimate regarding content validity (Hyrkäs, AppelqvistSchmidlechner, \& Oksa, 2003). Finally, a sufficient number of judges were obtained for the different areas being evaluated, which were between 11 and 20 contributors, depending on the areas, and availability and actual participation of the experts (seeTable 2)

Table 2 Distribution of Judges by Areas of Digital Competence

\begin{tabular}{lll} 
Area & Number of judges per Area & Total number of judges \\
\hline 1.- Information and informational literacy & 20 & 77 \\
2.- Communication and collaboration & 17 & \\
3.- Creation of digital contents & 11 & \\
4.- Security & 11 & \\
5.-Problem solving & 18 & \\
\hline
\end{tabular}

The 77 judges participating in the study belonged to different educational contexts (primary, secondary, university and different levels of management within training centres), $33 \%$ were women, the average number of years teaching was 19.36 , and all had experience related to educational innovation and the integration of ICTs. The characteristics of the sample are presented in Table 3. 
Table 3 Characteristics of the sample of judges

\begin{tabular}{|c|c|c|}
\hline Variable & Category & Number of judges \\
\hline \multirow[t]{6}{*}{ Autonomous Community } & Cantabria & 29 \\
\hline & Castile and Leon & 23 \\
\hline & Galicia & 4 \\
\hline & Madrid & 11 \\
\hline & Latin America & 2 \\
\hline & No answer & 8 \\
\hline \multirow[t]{2}{*}{ Sex } & Female & 33 \\
\hline & Male & 44 \\
\hline \multirow[t]{4}{*}{ Professional area ${ }^{*}$} & Primary & 27 \\
\hline & Secondary - Upper Secondary & 12 \\
\hline & University & 50 \\
\hline & Manager-advisor-inspector & 15 \\
\hline \multirow[t]{3}{*}{ Experience in innovation and ICT processes } & Some & 17 \\
\hline & Quite a lot & 48 \\
\hline & A lot & 12 \\
\hline
\end{tabular}

Note: ${ }^{*}$ Some teachers were included in more than one category

\subsection{Step three. Application of the assessment questionnaire}

Regarding the methodology to determine the content validity of an instrument, although various strategies can be adopted, qualitative or quantitative (Carrió, Soler, \& Aymerich, 2015; Urrutia, Barrios, Gutiérrez, \& Mayorga, 2014), questionnaires are the most commonly used method for obtaining information to facilitate the process of expert assessment, so it was prepared and sent to the judges.

In order to facilitate the process of assessment and collection of information, a questionnaire (for each of the areas) was prepared and sent to the judges. The assessment questionnaire was preceded by an explanatory text about the research project, the goals of the work and the use of the results of the validation process, as well as the instructions on how to answer the questionnaire.

The questionnaire consisted of two parts. The first part contained a series of questions regarding the identification and characteristics of the expert, such as residence, sex, professional environment, years of experience and experience with processes of innovation and ICT integration. The second part of the questionnaire contained items referring to the indicators of a single area of digital competence. Each indicator was assessed in relation to three characteristics: importance, relevance and clarity, defined as follows:

1. Importance: degree to which the indicator could measure competence.

2. Relevance: the suitability of the indicator with respect to the level of competence.

3. Clarity: the suitability of the wording of the indicator (does not lead to different interpretations).

A four-level Likert scale was used (4-a lot, 3-quite a lot, 2-little and 1-none), and each item also had a space for writing comments that allowed the judges to incorporate their own 
suggestions regarding a particular item. This was especially important if they did not consider the item to be pertinent or if the judges wished to make suggestions or provide more suitable responses, level changes, etc.

The questionnaire was made available to the experts using Google Forms, which was sent via e-mail. The judges were then able to fill in the questionnaire when it was most convenient for them to do so.

The process of constructing and validating the bank of indicators followed the guidelines proposed by other researchers (Barroso \& Cabero, 2010; Quiroz, Miranda, Gisbert, Morales, \& Onetto, 2016). This included a systematic review of the literature on digital competence, the procedures and processes for evaluating it; the review of models and assessment tests proposed by other researchers adjusted to the DIGCOM framework; and the development and validation of a model appropriate for the purposes of this study.

\subsection{Step four. Analysis of content validity}

The analysis o Lawshe (1975) the expert assessments and the level of agreement between judges were carried out following the method proposed by Lawshe (1975) and the review by Tristán-López (2008).

Lawshe (1975) proposed a method for determining a quantitative index for the content validity of an objective instrument, called the Content Validity Ratio (CVR), which is based on measuring agreement among judges concerning certain categories called essentials (Almanasreh, Moles, \& Chen, 2019). On the other hand, Tristán-López (2008) formulates a new proposal for the determination of instrument validity indices. The new model defines a new indicator $\left(\mathrm{CVR}^{\prime}\right)$ of agreement among judges that does not require a large number of judges and is easy to interpret and is based on standardization. The minimum value of agreement is a constant proportion of the number of judges, when standardizing the statistic CVR', where a consensus of at least $58.23 \%$ must be reached in order for an item to be accepted. Once the CVR'values have been obtained for each item, it is then possible to determine the CVI (Content Validity Index) of an instrument or bank of items, which in our case is the indicator model.

\section{RESEARCH RESULTS}

A panel of 77 experts (judges) was established for validating the INCODIES indicator model used to assess the digital competence of school students.

The number of judges assessing each area was greater than the minimum number indicated in the Tristán-López (2008) models, exceeding 10 judges in all cases.Table 4 presents the number of judges, the number of indicators that were evaluated in each area and the total number of assessments provided by the judges, considering that each indicator was evaluated respect to three characteristics (importance, relevance, and clarity).

The expert assessment concentrated on the content of the item. Once the evaluation of the items (model indicators) had been carried out by all judges involved in each of the areas, the validity analysis required that the number of agreements among the judges, or 
Table 4 Number of judges and items in each of the areas comprising the model

\begin{tabular}{lllllll} 
Scale & Area 1 & Area 2 & Area 3 & Area 4 & Area 5 & TOTAL \\
\hline No. of judges & 20 & 17 & 11 & 11 & 18 & 77 \\
No. of indicators & 48 & 69 & 102 & 72 & 65 & 356 \\
Judge assessments & 144 & 207 & 306 & 216 & 195 & 1068 \\
\hline
\end{tabular}

coincidences in the higher-ranking category (which we call essential, according to Lawshe's method) be determined.

Given the high number of indicators, the data obtained for the five areas was presented globally and not just item by item. The index of agreement among the judges in the three characteristics valued (importance, pertinence and clarity) and the validity of the proposal of indicators of each area of the digital competence could be observed. TheTable 5 shows the sum of the CVR' for the set of items included in the model, the number of items that obtained a positive evaluation by the judges $(\mathrm{M})$, and whether the items had been considered acceptable or not based on the three different characteristics. The table also indicates the partial CVR'values related to each of the characteristics assessed and the total CVR'that would integrate the three aspects indicated.

Table 5 Content Validity Indexes (CVI') of the initial model.

\begin{tabular}{|c|c|c|c|c|c|c|c|c|c|}
\hline AREAS & No. of items & $\begin{array}{l}\text { No. } \\
\text { judges }\end{array}$ & of & $\begin{array}{l}\text { Characteristic } \\
\text { assessed }\end{array}$ & $\begin{array}{l}\text { Sum of items } \\
\text { CVR' }^{\prime}\end{array}$ & $\mathbf{M}$ & Acceptable & $\begin{array}{l}\text { Partial } \\
\text { CVI' }^{\prime}\end{array}$ & $\begin{array}{l}\text { Total } \\
\text { CVI' }\end{array}$ \\
\hline \multirow[t]{3}{*}{ Area 1} & 48 & 20 & & Importance & 46.84 & 48 & YES & 0.976 & 0.958 \\
\hline & & & & Relevance & 46.35 & 48 & YES & 0.966 & \\
\hline & & & & Clarity & 44.73 & 48 & YES & 0.932 & \\
\hline \multirow[t]{3}{*}{ Area 2} & 69 & 17 & & Importance & 66.58 & 69 & YES & 0.965 & 0.933 \\
\hline & & & & Relevance & 63.82 & 69 & YES & 0.925 & \\
\hline & & & & Clarity & 62.79 & 69 & YES & 0.910 & \\
\hline \multirow[t]{3}{*}{ Area 3} & 102 & 11 & & Importance & 88.50 & 102 & YES & 0,885 & 0.867 \\
\hline & & & & Relevance & 85.85 & 102 & YES & 0.850 & \\
\hline & & & & Clarity & 88.23 & 102 & YES & 0.865 & \\
\hline \multirow[t]{3}{*}{ Area 4} & 72 & 11 & & Importance & 70.20 & 72 & YES & 0.975 & 0.960 \\
\hline & & & & Relevance & 69.84 & 72 & YES & 0.970 & \\
\hline & & & & Clarity & 67.32 & 72 & YES & 0.935 & \\
\hline \multirow[t]{3}{*}{ Area 5} & 65 & 18 & & Importance & 61.42 & 65 & YES & 0.945 & 0.910 \\
\hline & & & & Relevance & 58.82 & 65 & YES & 0.905 & \\
\hline & & & & Clarity & 57.20 & 65 & YES & 0.880 & \\
\hline \multirow[t]{3}{*}{ TOTAL } & 356 & 77 & & Importance & 333.54 & 353 & YES & 0.945 & 0.924 \\
\hline & & & & Relevance & 324,68 & 353 & YES & 0.945 & \\
\hline & & & & Clarity & 320,27 & 353 & YES & 0.945 & \\
\hline
\end{tabular}

Whereas:

$\mathrm{M}=$ Number of items with CVR'values $\geq 0.5823$

Acceptable $=95 \%$ of the items have CVR'values $>0.5823$

Partial CVI' $=\sum \mathrm{CVR}^{\prime} / \mathrm{M}$ obtained for the set of items on each aspect assessed (importance, relevance and clarity)

Total CVI' $=$ Average of the all partial CVI' 
In the data presented in table 5, it can be observed that in the areas of the model (except for area 3), the characteristic with the least amount of agreement among experts was clarity (although in all cases the number of agreements in the essential category is high), with importance and relevance achieving a slightly higher rating. Therefore, we can affirm that each of the indicators presented in the model is central for assessing digital competence. In addition, the indicators were correctly organized into the three levels of development, although some indicators could be worded more clearly. This issue will be taken into account when reviewing the formulation of the indicators with the lowest CVR'value.

With respect to the area of Information, it was observed that the indicators were satisfactorily evaluated by the 20 judges. It was confirmed that all of the CVR'indices obtained values higher than 0.58 (minimum consensus value in the essential category). This allowed us to affirm that all indicators within this section of the model had sufficient importance, relevance and clarity and could be considered as a bank of items with solid validity (table 5). The total content validity index (CVI') was 0.96 points, which is high considering that validity started from 0.58 with a maximum of 1 .

In area 2 on Communication, the work was carried out by a panel of 17 experts, who had positively rated the 69 items presented in the model. The validity index obtained a score of 0.93 , which meant that a large majority of judges accepted the items included within this area $(C V R>0.58)$. All of the partial CVI'ranged between 0.91 and 0.96 , the latter value referring to the importance of the items. These results allowed us to conclude that the proposed indicators were highly relevant for evaluating the students' digital competence.

Content Creation, in area 3, was validated by 11 experts. Most of the judges positively evaluated the 102 items included within this section. Overall, the experts accepted all items in this area $(\mathrm{CVR}>0.58)$, and a total validity index of 0.87 was attained. This index was the lowest of all 5 areas, which meant the indicators with less agreement needed to be revised to improve their validity.

The evaluation of Security, in area 4, was made by 11 judges, most of whom evaluated the 72 items of the model as excellent. In this case, some indicators were given a maximum score and achieved a total validity of $\mathrm{CVI}^{\prime}=0.96$, which can be considered as being highly satisfactory. The scores of the three characteristic rated ranged between 0.93 and 0.97 ; therefore, validity was justified given that the indicators had a high level of importance, relevance and clarity.

Finally, in area 5 on Problem Solving, the model was presented to a panel of 18 judges. Most of the judges evaluated the 65 indicators positively, placing them in the essential category. In addition, it should be noted that three judges coincided in their assessment of all the proposed indicators in the essential category. We can affirm that the bank of indicators proposed for this area was highly satisfactory, attaining a total validity index of $\mathrm{CVI}^{\prime}=0.91$.

Despite the high validity of the model, it was also considered relevant to review the items that had received lower evaluations, especially those within area 3 . The items with the least agreement among judges were reviewed, taking into account the experts' opinions and the suggestions expressed in the open questions. In some cases, the wording of the indicators was clarified and in others the indicators were eliminated. 
As a result, the wording of $7 \%$ of the indicators was reformulated, based on the considerations of the judges, and 31 indicators were eliminated from the initial 356 ( 3 from area 1,3 from area 2, 16 from area 3, none from area 4 and 9 from area 5). Consequently, the definitive model consisted of 325 indicators.

The changes and improvements made to the indicators added greater clarity to the wording of several items, and slightly increased the content validity index of the indicators of areas 3 and 5. Table 6 presents the validity data for the definitive indicator model. The complete model can be consulted in the aforementioned institutional repository.

Table 6 Content Validity Indexes (CVI') of the definitive model.

\begin{tabular}{|c|c|c|c|c|c|c|c|c|}
\hline AREAS & No. of items & No. of judges & Characteristic assessed & Sum of items CVR' & $\mathbf{M}$ & Acceptable & Partial CVI' & Total CVI' \\
\hline \multirow[t]{3}{*}{ Area 1} & 45 & 20 & Importance & 43.99 & 45 & YES & 0.977 & 0.959 \\
\hline & & & Relevance & 43.60 & 45 & YES & 0.969 & \\
\hline & & & Clarity & 41.93 & 45 & YES & 0.932 & \\
\hline \multirow[t]{3}{*}{ Area 2} & 66 & 17 & Importance & 63.70 & 66 & YES & 0.965 & 0.933 \\
\hline & & & Relevance & 61.06 & 66 & YES & 0.925 & \\
\hline & & & Clarity & 59.97 & 66 & YES & 0.910 & \\
\hline \multirow[t]{3}{*}{ Area 3} & 86 & 11 & Importance & 76.11 & 86 & YES & 0.885 & 0.882 \\
\hline & & & Relevance & 74.10 & 86 & YES & 0.862 & \\
\hline & & & Clarity & 77.43 & 86 & YES & 0.900 & \\
\hline \multirow[t]{3}{*}{ Area 4} & 72 & 11 & Importance & 70.20 & 72 & YES & 0.975 & 0.960 \\
\hline & & & Relevance & 69.84 & 72 & YES & 0.970 & \\
\hline & & & Clarity & 67.32 & 72 & YES & 0.935 & \\
\hline \multirow[t]{3}{*}{ Area 5} & 56 & 18 & Importance & 53.00 & 56 & YES & 0.946 & 0.920 \\
\hline & & & Relevance & 50.58 & 56 & YES & 0.903 & \\
\hline & & & Clarity & 48.96 & 56 & YES & 0.912 & \\
\hline \multirow[t]{3}{*}{ TOTAL } & 325 & 77 & Importance & 307.00 & 325 & YES & 0.945 & 0.925 \\
\hline & & & Relevance & 299,18 & 325 & YES & 0,92 & \\
\hline & & & Clarity & 295,61 & 325 & YES & 0,91 & \\
\hline
\end{tabular}

Graph 1 shows the content validity index scores of the three characteristics assessed for each item (importance, relevance and clarity), with values ranging from 0.85 to 0.97 (7695\% according to the judges). It can be observed that there was a high level of overall acceptance of the indicators, considering that the minimum score for a valid model of indicators was 0.5823 , out of a maximum score of 1 , guaranteeing a high validity index for the complete model.

The results obtained allowed us to affirm that the competences of the chosen reference model (DIGCOMP) were correctly represented by the complete model of indicators, which obtained high content validity based on the judgments made by the experts.

\section{DISCUSSION}

Digital competence is a basic skill for citizens of today's society and should be assessed in a systematic way taking into account the components of knowledge, skills and attitudes (Hazar, 2018). However, measuring and identifying student digital competence is 


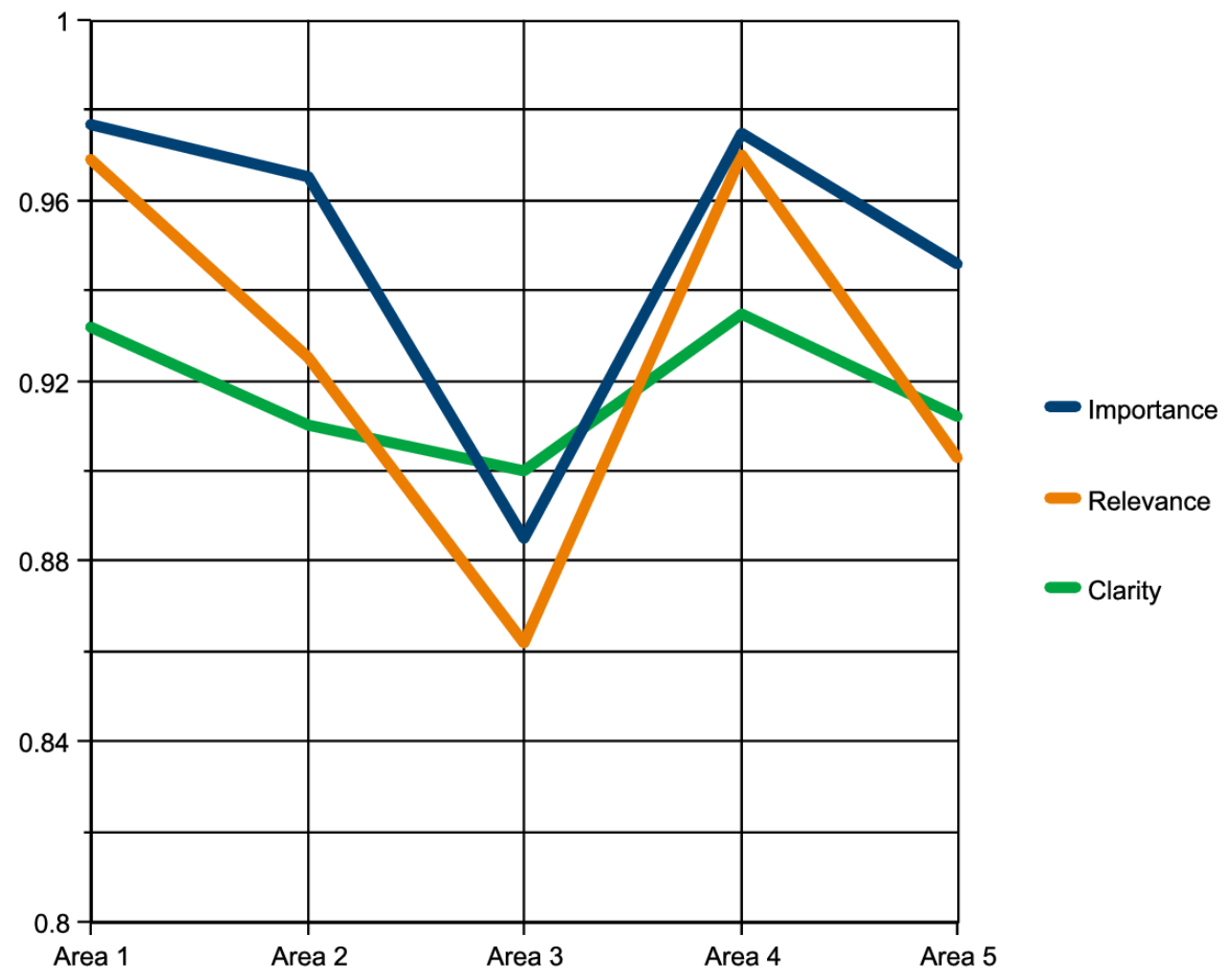

Figure 1 Content Validity Index of the model of indicators, according to areas and the evaluation of the importance, relevance and clarity of the items.

still a great challenge, as pointed out by

Colás et al. (2017).

The research objective has been achieved and provides a new and complete indicator model for the evaluation of student digital competence, identifying 325 items that cover the 21 competencies of the DIGCOMP. The model that has been published openly, so it is accessible to the entire educational and scientific community. The INCODIES model has been validated successfully and could serve as a reference for the development of tests for the evaluation of students' digital competence. This model covers the 5 areas of digital competence (Information, Communication, Content Creation, Security and Problem Solving), 3 components (knowledge, skills and attitudes) and 3 levels (basic, intermediate and advanced). This model is novel, because although matrices of indicators have been developed to evaluate digital competence, in most cases they are aimed at teachers (Quiroz et al., 2016) or focus on the how the students perceive their own use of digital resources in general (Fernández-Miravete, 2018).

The validation process of the INCODIES model for the evaluation of student digital competence has provided us with a large amount of useful information from the 77 experts who collaborated in the study. It has also allowed us to confirm the relevance, clarity and importance of the items, as well as the opportunity to reformulate and improve some of the 
indicators. Likewise, the joint work involving the discussion and debate of each of the indicators of the model, by the research group (10 researchers), has been essential for adjusting the formulation of the indicators to the reference population and the specific content of each competence.

Considering content validity as a sampling of the universe of possible behaviours, according to what is intended to be measured (Escobar-Pérez \& Cuervo-Martínez, 2008), the overall validity of the model of indicators can be considered highly satisfactory, with an optimal result (Global validity index $\left.\mathrm{CVI}^{\prime}=0.925\right)$ in all areas and competences. The INCODIES model, comprising 325 items, can be considered appropriate for the intended purposes. Once assessed by the experts, the model obtained a very high overall validity index. Moreover, it can be appreciated how the CVI'of all the areas included within the model positively exceed the minimum index established for the three characteristics evaluated: the importance of the item, relevance to the level to which it was defined; and clarity in its expression. Thus, we can say that the selected items measure the dimensions of the construct. As Ding and Hershberger (2002) state, the essential concept of content validity is that the items must be relevant and representative of the construct for a particular evaluative purpose.

\section{CONCLUSION}

We can affirm that we have a valid indicator model, in terms of content, aimed at evaluating the digital competence of students who had completed their compulsory schooling. Nevertheless, the model can also be used as a reference for other educational levels and even for the population in general. The validity analysis proposals of Lawshe and Tristán-López (2008) have been useful to validate models with a large number of items and have been used to show that this model is of high quality with respect to the validity of its content, and can serve as a structure and basis for the designing of specific evaluation tests on this topic. However, the evolution of the construct and the emergence of new problems related to digital competence will have to be taken into account so that it can continue to be revised and updated.

The main limitation of the aforementioned proposal is the wide extension of the model due to the fact that it has a very high number of indicators as it tries to cover all competencies and levels. Thus, researchers and educators should be the ones responsible for making a selection based on their specific evaluation objectives and the type of test they wish to design. Finally, it is proposed to apply other validation models of a qualitative nature for future research that provide complementary information and make it possible to prioritize the indicators according to different educational contexts.

\section{ACKNOWLEDGEMENTS}

Funded by: Ministry of Economy and Competitiveness, Spain

Funder Identifier: http://dx.doi.org/10.13039/501100003329 
Award: EDU2015-67975-C3-3-P

\section{REFERENCES}

Aesaert, K., \& Braak, J. V. (2014). Exploring factors related to primary school pupils' ICT selfefficacy: A multilevel approach. Computers in Human Behavior, 41, 327-341. https://doi.org/ 10.1016/j.chb.2014.10.006

Aesaert, K., Voogt, J., Kuiper, E., \& Braak, J. V. (2017). Accuracy and bias of ICT self-efficacy: An empirical study into students' over- and underestimation of their ICT competences. Computers in Human Behavior, 75, 92-102. https://doi.org/10.1016/j.chb.2017.05.010

Ait, E., \& González, J. (2017). Instruments per a l’avaluació de la competència digital de l'alumnat de secundària. UTE. Revista de Ciències de l'Educació, 1, 21-34. http://dx.doi.org/10.17345/ ute.2017.1.1747

Ala-Mutka, K. (2011). Mapping Digital Competence: Towards a Conceptual Understanding (and others, Ed.). Luxemburgo: JRC-IPTS European Commission. Retrieved from http://ipts.jrc .ec.europa.eu/publications/pub.cfm?id=4699

Almanasreh, E., Moles, R., \& Chen, T. (2019). Evaluation of methods used for estimating content validity. Research in Social and Administrative Pharmacy, 15(2), 214-221. https://doi.org/ 10.1016/j.sapharm.2018.03.066

Amaro, A. C., Oliveira, L., \& Veloso, A. I. (2017). Intergenerational and collaborative use of tablets: «in-medium» and «in-room» communication, learning and interaction. Observatorio (OBS), 11(1), 83-94. https://doi.org/10.15847/obsOBS1102017995

Barroso, J., \& Cabero, J. (2010). La investigación educativa en TIC. Visiones prácticas (and others, Ed.). Madrid: Síntesis.

Calvani, A., Fini, A., Ranieri, M., \& Picci, P. (2012). Are young generations in secondary school digitally competent? A study on Italian teenagers. Computers \& Education, 58(2), 797-807. https://doi.org/10.1016/j.compedu.2011.10.004

Cameron, L., Wise, S. L., \& Lottridge, S. M. (2007). The development and validation of the information literacy test. College \& Research Libraries, 68(3), 229-237. https://doi.org/10.5860/ crl.68.3.229

Carrió, C., Soler, M., \& Aymerich, M. (2015). Análisis de la Validez de Contenido de un Cuestionario de Evaluación del Aprendizaje Basado en Problemas: Un Enfoque Cualitativo. Formación universitaria, 8(1), 13-22. https://dx.doi.org/10.4067/S0718-50062015000100003

Colás, P., Conde, J., \& Reyes, S. (2017). Competencias digitales del alumnado no universitario. Revista Latinoamericana de Tecnología Educativa, 16(1), 7-20. https://doi.org/10.17398/1695 -288X.16.1.7

Dardanou, M., \& Kofoed, T. (2019). It is not only about the tools! Professional digital competence. In G. Colette \& I. Palaiologou (Eds.), Early learning in the digital age (pp. 61-76). London: SAGE Publications.

Ding, C., \& Hershberger, S. (2002). Assessing content validity and content equivalence using structural equation modeling. Multidisciplinary Journal, 9(2), 283-297. https://doi.org/10.1207/ S15328007SEM0902_7

Dornaleteche, J., Buitrago, A., \& Moreno, L. (2015). Categorización, selección de ítems y aplicación del test de alfabetización digital online como indicador de la competencia mediática. Comunicar, 22(44), 177-185. https://doi.org/10.3916/C44-2015-19

Enochsson, A. (2019). Teenage pupils' searching for information on the Internet. Information Research, 24(1). Retrieved from http://www.informationr.net/ir/24-1/isic2018/isic1822.html 
Escobar-Pérez, J., \& Cuervo-Martínez, A. (2008). Validez de contenido y juicio de expertos: una aproximación a su utilización. Avances en Medición, 6, 27-36.

Esteve, F., Gisbert, G., \& Lázaro, J. L. (2016). La competencia digital de los futuros docentes: ¿cómo se ven los actuales estudiantes de educación? . Perspectiva Educacional. Formación de Profesores, 55(2), 38-54. https://doi.org/10.4151/07189729

European Comission. (2007). Competencias clave para un aprendizaje a lo largo de la vida un marco de referencia europeo. Bélgica: Comunidades Europeas.

Fernández-Miravete, A. D. (2018). La competencia digital del alumnado de Educación Secundaria en el marco de un Proyecto educativo TIC (1:1). Edutec. Revista Electrónica de Tecnología Educativa, 63, 60-72. https://doi.org/10.21556/edutec.2018.63.1027

Ferrari, A. (2013). DIGCOMP: A Framework for Developing and Understanding Digital Competence in Europe. Sevilla: Joint Research Centre, Institute for Prospective Technological Studies. http://dx.doi.org/10.2788/52966

García, R., Duarte, A., \& Guerra, S. (2014). Propuesta de un instrumento de evaluación para medir el grado de competencia mediática en la etapa de la educación infantil. . Pixel-Bit: Revista de medios y educación, 44, 81-96. https://doi.org/10.12795/pixelbit.2014.i44.06

García-Valcárcel, A. (2016). Las competencias digitales en el ámbito educativo. Retrieved from http://hdl.handle.net/10366/130340

García-Valcárcel, A., \& Tejedor, F. J. (2017). Percepción de los estudiantes sobre el valor de las TIC en sus estrategias de aprendizaje y su relación con el rendimiento. Educación XXI, 20(2), 137-159. https://doi.org/10.5944/educxx1.19035

Gisbert, M., Espuny, C., \& González, J. (2011). INCOTIC. Una herramienta para la @utoevaluación diagnóstica de la competencia digital en la universidad. Profesorado: Revista de curriculum y formación del profesorado, 15(1), 75-90.

Gisbert, M., \& Esteve, F. (2011). Digital learners: la competencia digital de los estudiantes universitarios. La cuestión universitaria, 7, 48-59.

González, J., Espuny, C., Cid, M. J. D., \& Gisbert, M. (2012). INCOTIC-ESO. Cómo autoevaluar y diagnosticar la competencia digital en la Escuela 2.0. Revista de Investigación Educativa, 30(2), 287-302. https://doi.org/10.6018/rie.30.2.117941

Hazar, E. (2018). Digital competence in primary education: The case of Turkish language, mathematics and personal and social development courses. International Online Journal of Education and Teaching (IOJET), 5(2), 443-458.

Hernández, A., \& Iglesias, A. (2017). La importancia de las competencias digitales e informacionales para el desarrollo de una escuela intercultural. Interacçoes, 43, 205-232. https://doi.org/10 .25755/int.12038

Hyrkäs, K., Appelqvist-Schmidlechner, K., \& Oksa, L. (2003). Validating an instrument for clinical supervision using an expert panel. International Journal of nursing studies, 40(6), 36-37. https://doi.org/10.1016/S0020-7489(03)00036-1

ISTE. (2016). ISTE Standards for students. Retrieved from http://www.iste.org/standards/ISTE -standards/standards-for-students

Katz, I. R. (2007). Testing information literacy in digital environments: ETS's iSkills assessment. Information technology and Libraries, 26(3), 3-12. https://doi.org/10.6017/ital.v26i3.3271

Lawshe, C. H. (1975). A quantitative approach to content validity. Personnel psychology, 28(4), 563-575. http://dx.doi.org/10.1111/j.1744-6570.1975.tb01393.x

Lee, L., Chen, D. T., Li, J. Y., \& Lin, T. B. (2015). Understanding new media literacy: The development of a measuring instrument. Computers \& Education, 85, 84-93. https://doi.org/10.1016/j .compedu.2015.02.006

Matamala, C. (2014). Factores predictivos de las competencias TIC en alumnos chilenos de 
secundaria. Revista iberoamericana de educación, 67(1), 121-136. https://doi.org/10.35362/ rie671267

MEC-INTEF. (2017). Marco común de la Competencia Digital Docente. Retrieved from http://aprende.educalab.es/wp-content/uploads/2017/11/2017_1020_Marco-Com\%C3\% BAn-de-Competencia-Digital-Docente.pdf

Oakleaf, M. (2008). Dangers and Opportunities: A Conceptual Map of Information Literacy Assessment Approaches. Portal: Libraries and the Academy, 8(3), 233-253. https://doi.org/10.1353/ pla.0.0011

Pinto, M. (2009). Design of the IL-HUMASS survey on information literacy in higher education: A self-assessment approach. Journal of Information Science, 36(1), 86-103. https://doi.org/ $10.1177 / 0165551509351198$

Pinto, M., \& Guerrero, D. (2017). Cómo perciben las competencias informacionales los estudiantes universitarios españoles: un estudio de caso. Investigación bibliotecológica. Investigación bibliotecológica, 31(73), 213-236. http://dx.doi.org/10.22201/iibi.24488321xe.2017.73.57854

Quiroz, J. S., Miranda, P., Gisbert, M., Morales, J., \& Onetto, A. (2016). Indicadores para evaluar la competencia digital docente en la formación inicial en el contexto Chileno-Uruguayo. RELATEC, 15(3), 55-68. https://doi.org/10.17398/1695-288X.15.3.55

Rodríguez, M. J., Olmos, S., \& Martínez, F. (2012). Propiedades métricas y estructura dimensional de la adaptación española de una escala de evaluación de competencia informacional autopercibida (IL-HUMASS). Revista de Investigación Educativa, 30(2), 347-365. https://doi.org/ 10.6018/rie.30.2.120231

Scherer, R., Rohatgi, A., \& Hatlevik, O. (2017). Students' profiles of ICT use: Identification, determinants, and relations to achievement in a computer and information literacy test. Computers in Human Behavior, 70, 486-499. https://doi.org/10.1016/j.chb.2017.01.034

Siddiq, F., Hatlevik, O. E., Olsen, R. V., Throndsen, I., \& Scherer, R. (2016). Taking a future perspective by learning from the past - A systematic review of assessment instruments that aim to measure primary and secondary school students' ICT literacy. Educational Research Review, $19,58-84$.

Stopar, K., \& Bartol, T. (2019). Digital competences, computer skills and information literacy in secondary education: mapping and visualization of trends and concepts. Scientometrics, 118(2), 479-498. https://doi.org/10.1007/s11192-018-2990-5

Tristán-López, A. (2008). Modificación al modelo de Lawshe para el dictamen cuantitativo de la validez de contenido de un instrumento objetivo. Avances en Medición, 6, 37-48.

Urrutia, M., Barrios, S., Gutiérrez, M., \& Mayorga, M. (2014). Optimal method for content validity. Revista cubana de educación médica superior. Revista cubana de educación médica superior, 3, 547-558.

Van Deursen, A., Helsper, E. J., \& Eynon, R. (2016). Development and validation of the Internet Skills Scale (ISS). Information, Communication \& Society, 19(6), 804-823. https://doi.org/ 10.1080/1369118X.2015.1078834

Van Deursen, A., \& Van Diepen, S. (2013). Information and strategic Internet skills of secondary students: A performance test. Computers \& Education, 63, 218-226. https://doi.org/10.1016/ j.compedu.2012.12.007

Van Deursen, A., \& Van Dijk, J. (2011). Internet skills and the digital divide. New media \& Society, 13, 893-911. https://doi.org/10.1177/1461444810386774

Vuorikari, R., Punie, Y., Carretero, S., \& Brande, L. V. D. (2016). DigComp 2.0: The digital competence framework for citizens Scientific and Policy Report. Seville: Joint Research Centre of the European Commission. 